\title{
PTI TECHNICAL ASSISTANCE TO REBUILD AMERICA
}

\section{TECHINICAL PROGRESS REPORT}

For the Period:

October 2001 - March 2002

\author{
Submitted to: \\ Rebuild America \\ The Department of Energy \\ DOE Award Number - DE-FC26-01NT41107
}

\author{
Submitted by: \\ Public Technology, Inc. \\ 1301 Pennsylvania Ave., N.W. \\ Suite 800 \\ Washington, D.C. 20004
}

\begin{abstract}
"This report was prepared as an account of work sponsored by an agency of the United States Government. Neither the United States Government nor any agency thereof, nor any of their employees, makes any warranty, express or implied or assumes any legal liability or responsibility for the accuracy, completeness, or usefulness of any information, apparatus, product, or process disclosed, or represents that its use would not infringe upon privately owned rights. Reference herein to any specific commercial product, process, or service by trade name, trademark, manufacturer otherwise does not necessarily constitute or imply its endorsement, recommendation, or favoring by the United States Government or any agent thereof. The views and opinions of authors expressed herein do not necessarily state or reflect those of the United States Government or any agency thereof."
\end{abstract}




\begin{abstract}
Public Technology Inc. (PTI) engaged in a cooperative agreement, DE-FC26-01NT41107, with the US Department of Energy's (DOE) Rebuild America Program to provide energy efficiency and energy conservation technical assistance to local governments across the United States. The first year of the cooperative agreement dated from April 2, 2001 to April 1, 2002, at a funding level of $\$ 375,000$. This technical report covers the period of October $2001-$ March 2002.

PTI appreciates the support that it has received from Rebuild America and plans to continue, with DOE and Rebuild America support, to serve in a strategic capacity, lending the technical experience of its staff and that of the Energy Task Force on approaches to increasing program efficiencies, furthering program development, and coordinating information sharing to help ensure that energy programs are responsive to the needs of local governments.
\end{abstract}




\section{TABLE OF CONTENTS}

I. Executive Summary

II. Experimental

III. Results and Discussion
A. Task One
B. Task Two
C. Task Three
D. Task Four

IV. Conclusion

V. References 


\section{Executive Summary}

Public Technology Inc. (PTI) engaged in a cooperative agreement, DE-FC26-01NT41107, with the US Department of Energy's (DOE) Rebuild America Program to provide energy efficiency and energy conservation technical assistance to local governments across the United States. The first year of the cooperative agreement dated from April 2, 2001 to April 1, 2002

PTI through its staff and membership liaisons at NLC, NACo and ICMA have kept in continual communication with Rebuild America Program Management regarding the current energy efficiency needs of local governments. PTI reported this useful and timely information at the quarterly Rebuild America Strategic Partner meetings.

\section{II.Experimental:}

This section is non-applicable to this report.

\section{Results and Discussion}

Task A: PTI will incorporate selected MEMP reports and other energy related publications from its sponsoring organizations into Rebuild America's Solutions Center.

PTI staff provided the following reports to the Rebuild America Program:

- Tools for the Job: How to Develop a Municipal Energy Plan-San Francisco, CA

- Creating Cool Communities: Phase I-Tucson, AZ

- The Yavapai-Apache Nation Power Reliability Study, Clarksdale, AZ

- Photovoltaic Purchasing Guidebook, Albuquerque, NM

Problems Encountered: PTI has over 400 reports that are housed here at our location. PTI staff will begin the process of relocating many of these reports, with the assistance of Aspens Systems, to the Rebuild America Solutions Center.

Task B: Revising the Sustainable Building Technical Manual (SBTM).

Public Technology Inc. (PTI) and its Urban Consortium Energy and Environment Task Forces, through the creation of the Sustainable Building Technical Manual (SBTM), addressed the design and construction of green buildings at the local level. The US Green Building Council (USBC) was also an integral partner in the creation of this manual.

It is estimated that over 2,000 copies of this manual have been purchased either through PTI or USGBC since 1996. State and federal government agencies, non-profit organizations, architects, design companies, universities, and private consultants have purchased the manual. 
After an extensive review by PTI and the Department of Energy's Rebuild America program representatives we concur that the manual needs modifications to the some of the existing chapters and additional information. PTI proposes the following chapters revisions from the original manual:

- Financing options for green building,

- New codes and standards including LEED,

- Operations and maintenance,

- Renewable energy sources and;

- Distributed generation.

In addition, we also propose that additional sections on site design, urban sprawl and building commissioning are included as well. Finally, that the entire manual will have a holistic sustainability approach to include recycling, urban sprawl, transportation, air and water quality.

PTI, the US Green Building Council, DOE and EPA were the original sponsors and coauthors of the SBTM. PTI staff was involved in the writing, editing, and printing of the original manual.

PTI will coordinate the effort to revise the manual as follows:

- Prepare proposals to secure funding from US Green Building Council (USGBC), EPA, US Department of Housing and Urban Development for a revision of the document.

- PTI will serve to coordinate the revision effort, and will also serve as editor.

- PTI will revise the manual for distribution over its website and in conjunction with its sponsoring organizations, NLC, NACo and ICMA.

- PTI proposes that the manual have an introductory hard copy but the entire manual will be on a CD-rom.

Problem Encountered: none.

Results: PTI submitted this proposal to a member of the US Green Building Council's Board of Directors for funding.

TASK C. Technical Peer-to-Peer Exchanges.

PTI has begun to coordinate peer-to-peer meetings with Rebuild America partners in Dayton, $\mathrm{OH}$ and Boston, MA. 
The following are preliminary details for the peer-to-peer exchange in Dayton, Ohio:

- Statement of Purpose;

- The Baseline Numbers;

- Goals and Objectives;

- Program Design;

- Implementation;

- Public Adoption of the Plan.

The Statement of Purpose provides an overview of the Dayton's energy goals, i.e. 10-20\% reduction of energy consumption for all municipal owned buildings or the reason for it and the anticipated outcomes. The Statement is basically broad principles, but it also provides background on the importance of energy to the functioning of the community, and the cost of providing energy services. The Statement could discuss the community's vulnerability to fluctuations in energy supply and cost, and also include a statement on the city's view of energy policy making and its place in the local and global environment. The purpose statement will also provide an overview of how the energy plan fits into City of Dayton's -2003 City Commission Adopted Budget.

The Baseline Numbers section describes energy use patterns within specific buildings, the building's history, where the patterns fall for the City now, and where they are going if the general energy use trends continue. This section includes, conventional fuel use, the status of renewable energy use, and of existing energy efficiency programs, i.e. LED's and street lighting retrofits.

The Goals and Objectives provide the long-term overarching direction for the Dayton energy plan and the intermediate steps necessary for eventual success. The goals should be broad enough to provide general direction, and solid enough to survive short-term changes to the objectives due to shifts in the immediate economic /environmental /political situation. The objectives could include, for example, reasonable energy reduction targets and details of how progress will be measured and evaluated.

Energy Programs are key components of action plans and are the vehicles through which the plan's objectives are reached. For example, if it is a municipality's goal to construct renewable energy systems, the associated implementation program may need to:

- Provide education on benefits;

- Develop political support;

- Encourage building owners to install systems;

- Train system installers;

- Provide incentives to reduce installation costs;

- Resolve net-metering problems with local utilities. 
The program designs will also include information on the staff, consulting, costs, political and other resources that will be necessary to achieve the program objectives, and will provide anticipated schedules, details of other agency's involvement, and other essential information. Without most of these components, the program is unlikely to be successfully implemented and the original goal will not be reached. The program design may also describe individual departmental responsibilities in the implementation of the plan.

Implementing the Plan - a successful plan will from the outset include descriptions of the actions necessary at the program level to ensure the plan's accomplishment. In general a plan should not include a separate implementation section. Instead the required program implementation activities should be presented as integrated parts of the program designs.

The Public Adoption of the Plan by the Mayor and City Commissioners and will provide essential public recognition by elected leaders that the goals expressed in the plan are also those held by the public's representatives, and that they do not just represent specialized minority interests. Very often these commissions and councils are the same ones that will eventually also be approving expenditures for future program implementation. So a public commitment to the goals and general direction of the energy plan, may improve the chances that the necessary resources will be made available.

A more detailed report including short term and long- term energy planning and management strategies are being developed for Boston, MA. PTI staff is suggesting the following points for Boston:

That an "energy champion" be identified to oversee the implementation of policy and process. This person should have the opportunity for regular contact with the Mayor as his leadership and support will be necessary for a successful program. The "energy champion" may come from one of the following departments:

- Budget

- Property Management

That the Mayor's office demand from NStar and Keyspan one year of bills for all COB accounts, including meter information from traffic lights.

That the Mayor issue an Executive Order (Order) that the Purchasing Department conduct an evaluation of available energy-efficient equipment and systems so that procurement, bidding and contract specification standards can be developed for use by all City departments.

That the Mayor's commitment to energy conservation and to reducing the City's energy usage by $10 \%$ and the variety of ways in which the City will meet that goal be publicized. Use this publicity to encourage changes in behavior and as a model for other entities. (Possible resources that the Mayor might describe include the use of the utilities' Public Benefits Fund and the proposal prepared for Rebuild America for software and planning.) 
That the City use Rebuild America's marketing and education tools (ex. software and energy management planning).

That the City develops and continues with an interagency energy management committee (upon completion of the work being done by the Mayor's Advisory Committee).

That an "energy champion" be designated in each City Hall department or on each floor. These individuals will use Rebuild resources for education and monitoring.

Thus far The City of Boston has identified a representative from Department of Property Management as the Rebuild America point of contact at the upcoming National Forum.

TASK D: Develop a "Critical Energy Infrastructure Workshop" at the Rebuild America National.

On February 2, 2002 PTI staff submitted the following descriptions to Potomac Communications for two workshops at the Rebuild America National Forum in July 2002:

- A Program Management-Essentials for Energy Emergency Planning and Response: San Jose, CA developed a Sustainable Energy Emergency Action Plan for San Jose. A photovoltaic (PV) system was installed at a central key city location, and city officials coordinated with Emergency Managers Association to provide information on emergency disaster applications for PV. Presenter: Mary Tucker, San Jose, CA. (invited). Moderator: Sharron Brown, Director of Energy Programs, PTI.

Elise Rand from Potomac Communications submitted Essentials for Energy Emergency Planning and Response: San Jose, CA developed a Sustainable Energy Emergency Action Plan for San Jose to the Rebuild America National Forum Planning Committee. It was submitted to the committee in February 2002. We never received a response from the planning committee.

Results: The workshop will not occur at the National Forum.

PTI and the UCETF have a wealth of experience that is not recognized by the entire Rebuild America team including all the supporting contractors. PTI staff will make the necessary steps including speaking to representatives at the National Forum so that this type of occurrence will not happen again.

\section{Conclusion}

PTI appreciates the support and guidance that we have received from Rebuild America and the Department of Energy. We are very excited about the work that we have accomplished. We have made considerable strides in certain areas, and would certainly like to be able to continue this important work. We have restructured internally and have streamlined our research program 
to better meet the needs of our members and partners in a more effective and efficient manner. We all have much work to do within the realm of energy efficiency and energy conservation and PTI looks forward to working with Rebuild America and your network of partners to find solutions to real world energy issues that face local governments across the country.

\section{$\underline{\text { V.References }}$}

There are no references to report at this time. 